\title{
Effect of Minimum Wages on Inflation and Unemployment in East Java - Indonesia
}

\author{
I Made Suparta* Ujianto Murgianto \\ Faculty of Economics and Business, University of 17 Agustus 1945 Surabaya, \\ 45 Semolowaru Street, Surabaya, Indonesia
}

\begin{abstract}
Unemployment and inflation are two macroeconomic problems that have a trade-off, this means that the relationship between inflation and unemployment is negative and the relationship is also called the Phillips curve. The increase in the minimum wage is one of the causes of inflation and unemployment. This study aims to determine the relationship between minimum wage and inflation, the relationship between minimum wage and unemployment, the relationship between inflation and unemployment. This study uses panel data from 38 regions with the period 2010-2019 in East Java-Indonesia. Data is collected from the Central Bureau of Statistics of East Java. Data were analyzed with the Amos. The results showed that the real minimum wage had a negative and significant effect on inflation. Real minimum wages have a positive and significant effect on unemployment. Inflation has a positive and significant effect on unemployment. There is no trade-off between inflation and unemployment, this study does not support the Phillips curve. The real minimum wage has a direct negative effect on inflation, inflation has a positive effect on unemployment, thus causing the real minimum wage to have a negative effect indirectly on unemployment. The relationship between inflation and unemployment shows that higher inflation tends to lead to higher unemployment. The determination coefficient for inflation was 5.5 percent and the determination coefficient for unemployment was 2.3 percent.
\end{abstract}

Keywords: minimum wages, inflation, unemployment, Phillips Curve

DOI: $10.7176 / \mathrm{JESD} / 12-8-04$

Publication date: April $30^{\text {th }} 2021$

\section{Introduction}

Unemployment is a macroeconomic problem. The problem of unemployment is not peculiar to Indonesia alone, but all countries in the world experience it. Only the levels are different, some countries with high unemployment rates and some other countries with low levels. It is a common economic phenomenon faced by many countries both developed and less developed countries.

Many factors have been identified that cause unemployment pressure in Indonesia, such as the increase in the minimum wage which causes the number of goods produced to decrease which in turn reduces the number of workers employed, this means that it will also increase the number of unemployed. This means that a higher wage rate leads to a higher unemployment rate. In addition to the minimum wage, inflation can also increase unemployment, because inflation causes people's purchasing power to decrease so that it can reduce product demand and will cause additional unemployment.

The number of the labor force and unemployment in East Java in the 2014-2018 period is shown in Table 1.

Based on the data in Table 1, the number of the labor force in 2016 decreased by 320,835 people compared to 2015 due to the increasing number of population aged 15 years and over into the non-workforce group, especially those who manage the household and is caused by the decreasing working population. In 2015, the number of unemployed increased due to the additional workforce that year. In general, the unemployment rate can be reduced from year to year. An unemployment rate of 4 percent has been categorized as a natural unemployment rate or full employment activity.

Table 1. Labor Force and Unemployment in East Java (2014-2018)

\begin{tabular}{|c|c|c|c|}
\hline \multirow{2}{*}{ Year } & \multirow{2}{*}{ Workforce (people) } & \multicolumn{2}{|c|}{ Unemployment } \\
\cline { 3 - 4 } & $20,149,998$ & People & $\%$ \\
\hline 2014 & $20,274,681$ & 843,490 & 4.19 \\
\hline 2015 & $19,953,846$ & 906,904 & 4.47 \\
\hline 2016 & $20,937,716$ & 839,283 & 4.21 \\
\hline 2017 & $21,300,423$ & 838,496 & 4.00 \\
\hline 2018 & 850,474 & 3.99 \\
\hline
\end{tabular}

Source: Central Bureau of Statistics of East Java.

Another economic problem is inflation. Inflation as a general increase in prices can be seen from the change of prices recorded in the consumer price index (CPI). If the goods and services needed by most people have increased in price at a moderate or even very high level, it will be a burden for low-income people because most of their income will be spent on their needs. Thus, a moderate price increase or even a high increase will reduce 
the purchasing power of the people, especially middle-income and low-income people.

One of the causes of price increases is the increase in minimum wage rates. At higher wages, production costs will increase. In Indonesia, each company is required to pay its employees according to the minimum wage provisions set by the local government.

In Indonesia, minimum wage increases occur every year. That means that the costs to be paid by employers to the labor they use also increase which will eventually increase production costs. The determination of the minimum wage is set in each region both in the district and in the municipal.

The relationship between the minimum wage and the inflation rate has been done by several researchers. Research conducted by Brouillette, et al (2017) shows that minimum wages have a positive and significant impact on inflation. It's meaning that the higher rate of increase in the minimum wage causes an increase in the consumer price index to also increase or in the sense that an increase in the wage level is followed by an increase in the inflation rate. Unions usually demand higher minimum wages when inflation is high. As a result, higher minimum wages encourage higher inflation. The relationship between minimum wages and inflation is a spiral. There is a strong positive relationship between minimum wage increases and inflation (Ma, 2018). While Nguyen (2011) found that minimum wages had a negative but not significant impact on inflation. It's meaning that the higher rate of increase in the minimum wage causes a decrease in inflation.

The relationship between inflation and unemployment has been studied by several researchers whose results show that inflation significantly increases unemployment (Hasan \& Sun'an, 2019), (Anshori \& Suparta, 2018), (Idenyi et al, 2017). Inflation increases unemployment insignificantly (Adarkwa, 2017), (Al-zeaud, 2014), (Elliot, 2015). Conversely, inflation significantly reduces unemployment (Kasseh, 2018), (Macharia \& Otieno, 2015), (Sabir and Naz, 2015), (Shahid, 2014), (Thayaparan, 2014), (Arslan \& Zaman, 2014), (Doğan, 2012). Some also find inflation reduces unemployment insignificantly (Gyang, E.J., Anzaku, E., Iyakwari, A.D.B., \& Eze, 2018). There is a trade-off between inflation and unemployment. This means that if the government wants to reduce inflation, it will cause an increasing unemployment rate. The trade-off between inflation and unemployment is called the Phillips curve (Mankiw, 2000).

The relationship between minimum wage and unemployment has been done by Brunt \& Barilla (2018). In this study, it was found that the minimum wage had a positive and significant effect on unemployment.

Based on the description above, the purpose of this study is to analyze the effect of minimum wages on inflation, the effect of inflation on unemployment, and the effect of minimum wages on unemployment.

\section{Review of Literature}

\subsection{Minimum Wage}

The minimum wage is the lowest level of payment applied through a minimum wage fixing system, paid to workers based on employment contracts. The government implements a minimum wage policy that is aimed at protecting low-income workers.

The International Labor Organization defines minimum wages as "the minimum amount of remuneration required by the employer to pay the recipient of wages for work performed for a certain period, which cannot be reduced by collective labor agreements or individual contracts". The government sets minimum wages with the aim of protecting workers from wages that are too low (ILO, 2015). But in practice, minimum wages may differ in each country according to the political climate and in responding to various concerns about the unintended consequences of setting minimum wages on employment and in general, the competitiveness of companies that employ low-wage labor (Wascher, 2015).

\subsection{Inflation}

Inflation occurs when the general price level increases continuously. Inflation is measured as the rate of change in the consumer price index over time (Levcic \& Rebmann, 1986). To calculate the inflation rate, the Consumer Price Index is used which measures the general price level compared to the Consumer Price Index in a certain period as the base year. Then the inflation rate is calculated as a change in the Consumer Price Index in percent (Froyen, 2013). The Consumer Price Index is an index of the average prices of several goods and services that make up the Consumer Price Index. If in an economy there has been an increase in the Consumer Price Index, it means inflation has occurred in the economy.

\subsubsection{Cost-push inflation}

Cost-push inflation occurs when price pressure comes from the seller's side of the market. Pressure on prices can come from rising labor costs, raw materials, fuel, machinery, loans, and even efforts to increase profits. For example, an increase in energy costs affects almost every large or small seller in the economy. Increased health insurance costs borne by employers and higher health care costs will contribute to inflation (Welch \& Welch, 2010). Therefore cost-push inflation occurs due to increased production costs borne by the company which will further increase the price of goods and services to be paid by the buyer. Cost-push inflation tends to reduce the number of workers employed by companies or cause increased unemployment. 


\subsubsection{Demand-pull inflation}

Demand-pull inflation occurs when the demand for buyers to buy goods and services exceeds the ability of sellers to supply them, the prices of available goods and services rise. Demand-pull inflation has tends to occur when the economy is near or at full employment. Remember that at full employment, the economy is at full capacity. In these conditions, production cannot be easily expanded. At the same time, consumer demand for goods and services is high because more people work and have money to spend. This expenditure pressure by households and businesses, coupled with production at or near capacity, triggers inflation pull demand. Too much money in the economy and the hands of businesses and consumers can contribute to demand-pull inflation (Welch \& Welch, 2010). Therefore, demand-pull inflation is inflation that occurs as a result of an increase in aggregate demand, such as an increase in government spending, an increase in public consumption, an increase in civil servants' salaries, an increase in money supply, an increase in corporate investment, an increase in wages will increase demand for goods and services. Demand-pull inflation tends to increase the number of workers or reduce unemployment.

\subsection{Unemployment}

Unemployment is a percentage of the labor force that is not working (Froyen, 2013). Unemployment means workers belonging to the labor force who are not working and who are looking for work. Someone is considered unemployed if he is not working and is waiting to start a new job, is on leave, or is looking for work.

At a given wage level, unemployment is defined as the difference between the amount of labor supplied by households and the amount of labor demanded by companies (Kim \& Lim, 2018). At a higher wage level, the unemployment is higher, where the number of workers supplied by households is increasing and the number of workers demanded by companies is less. This can be seen from the gap between the labor demand curve and the labor supply curve which is getting bigger and the condition can be explained using Figure 1.

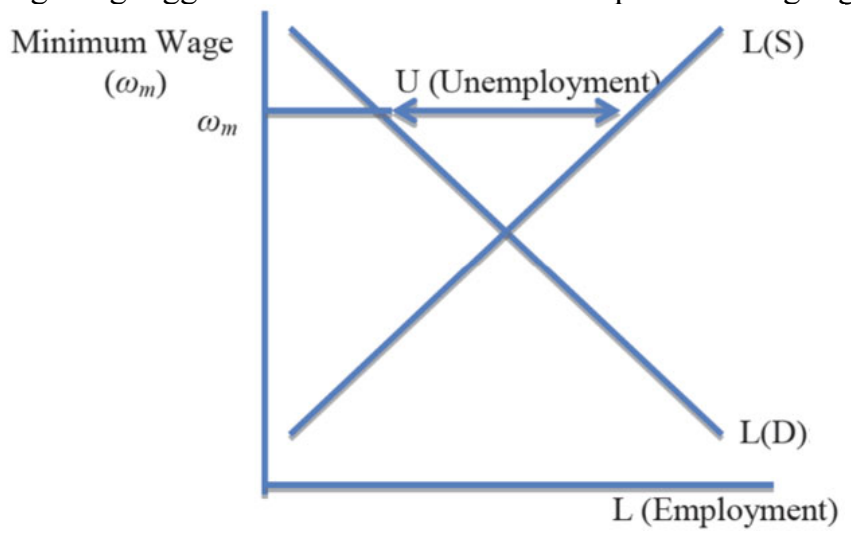

Source: (Kim \& Lim, 2018)

Pigure 1. The Labor Market

\section{Research Methodology \\ 3.1 Data}

Secondary data for the 2010-2019 period is used in this study, data is taken from the Central Bureau of Statistics of East Java. There are 29 regencies and 9 municipalities so that the number is 38 regions. Thus, this study uses panel data with a time series of 10 years and cross-section data of 38 regions.

\subsection{Variable Measurement}

\subsubsection{Measurements of the minimum wage}

The minimum wage is the amount of wage set by the local government which is enforced in 38 regions. In this study, the minimum wage variable is the change in the level of real minimum wages each year as measured by a percentage. The real minimum wage is calculated by dividing the nominal minimum wage by the implicit index for each year then multiplying by 100 .

3.2.2 Measurements of the inflation

Inflation is the level of change in the implicit index that occurred in 38 regions every year. Annual inflation is measured as a percentage.

3.2.3 Measurements of the unemployment

Unemployment is the ratio between the number of unemployed to the workforce.

Unemployment in this study is the rate of change in the unemployment rate in 38 regions each year as measured by a percentage. 


\subsection{Conceptual Framework}

The data collected is the observed variable data, therefore the conceptual framework used is shown in Figure 2.

Based on Figure 2 will be analyzed using Amos. This analysis will analyze the effect of minimum wage on inflation, analyze the effect of minimum wage on unemployment, and analyze the effect of inflation on unemployment.

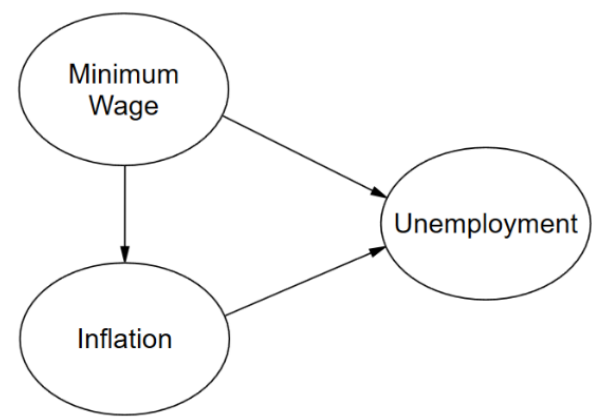

Figure 2. Conceptual Framework

\section{Analysis}

The variables in this study are observed variables, so the shape of all variables is rectangular. Based on the panel data that has been collected analyzed using Amos, the results obtained as in Figure 3.

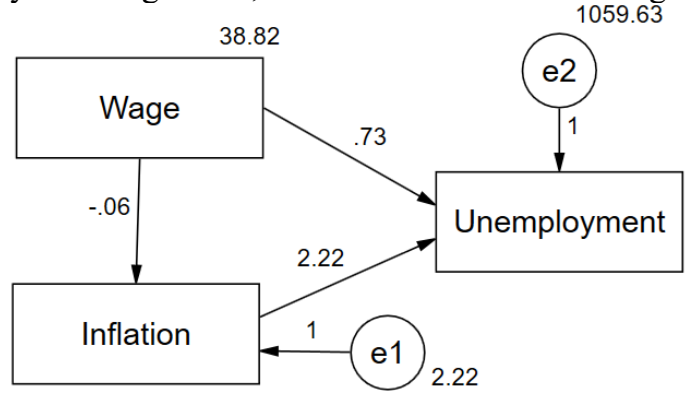

Source: Data analysis output

Figure 3. Regression Analysis with Amos

The analysis results contained in Figure 3 can be detailed as seen in Table 2, Table 3, Table 4, and Table 5. Table 2. Regression Weights

\begin{tabular}{|lll|rrrrr|}
\hline & & & Estimate & S.E. & C.R. & P & Label \\
\hline Inflation & $<---$ & Wage & -.058 & .012 & -4.713 & $* * *$ & par_3 \\
Unemployment & $<---$ & Wage & .734 & .276 & 2.657 & .008 & par_1 \\
Unemployment & $<---$ & Inflation & 2.220 & 1.122 & 1.979 & .048 & par_2 \\
\hline
\end{tabular}

Source: Data analysis output

Based on the results of the analysis in Table 2, the relationship between the minimum wage and inflation is negative, which means that if the minimum wage increases, there is a tendency for inflation to decrease and vice versa. The relationship between the minimum wage and unemployment is positive, meaning that if the minimum wage increases, there is a tendency for rising unemployment, and vice versa. While the relationship between inflation and unemployment is positive, meaning that if the minimum wage increases, there is a tendency for inflation to increases and vice versa.

Based on the results of the significance test, there is a negative and significant relationship between minimum wages and inflation because the significance value (column P) of 0.000 is less than 0.05 which is marked with three stars $(* * *)$. The results of this study reject the research of Brouillette et al. (2017), the minimum wages have a positive and significant impact on inflation. The minimum wage had a positive and significant relationship to unemployment because the significance (column P) of 0.008 is smaller than 0.05 . The results of this study support the research of Brunt \& Barilla (2018), the minimum wage had a positive and significant effect on unemployment. Inflation had a positive and significant relationship to unemployment because the magnitude of significance (column P) of 0.048 is lower than 0.05 . The results of this study support the research of Hasan \& Sun'an (2019), Anshori \& Suparta (2018), Idenyi et al (2017), inflation increases unemployment significantly. The relationship between inflation and unemployment shows that inflation tends to cause unemployment. 


\begin{tabular}{|c|c|c|}
\hline & Wage & Inflation \\
\hline Inflation & -.058 & .000 \\
\hline Unemployment & .734 & 2.220 \\
\hline
\end{tabular}

Source: Data analysis output

Based on the analysis in Table 3 it can be seen that the direct effect of minimum wages on inflation is negative with a value of -0.058 , this means that an increase in the minimum wage will reduce inflation. The direct effect of minimum wages on unemployment is positive with a value of 0.734 , this means that an increase in the minimum wage will increase inflation. And the direct effect of inflation on unemployment is positive with a value of 2.220 , this means that an increase in inflation will increase unemployment.

Tabel 4. Indirect Effects

\begin{tabular}{|l|rr|}
\hline & Wage & Inflation \\
\hline Inflation & .000 & .000 \\
Unemployment & -.129 & .000 \\
\hline
\end{tabular}

Source: Data analysis output

Table 5 shows the coefficient of determination of inflation and the coefficient of determination of unemployment. The amount of the inflation determination coefficient is very low, amounting to 0.055 or $5.5 \%$. This shows that only $5.5 \%$ of the variation in inflation is influenced by variations in the minimum wage. Thus many other variables influence inflation.

The coefficient of determination of unemployment is very low, amounting to 0.023 or $2.3 \%$. This shows that only $2.3 \%$ of the variation in unemployment is affected by variations in the minimum wage and variations in inflation. Thus many other variables influence unemployment.

Table 5. Squared Multiple Correlations

\begin{tabular}{|l|r|}
\hline & Estimate \\
\hline Inflation & .055 \\
Unemployment & .023 \\
\hline
\end{tabular}

Source: Data analysis output

\section{Conclusion}

The decreasing percentage of real minimum wage increase causes a significant increase in inflation, on the other hand, for a lower inflation rate, the government in East Java can achieve it with a higher rate of increase in the real minimum wage.

During the 2010-2019 period, the tendency for the rate of increase in real minimum wages increased in 38 regions in East Java, while the trend of the inflation rate that occurred in the same period was decreasing. Thus, the negative effect of the real minimum wage on inflation means that a higher rate of increase in the real minimum wage can increase the price of goods and services at a decreasing rate.

An increase in the real minimum wage causes a significant increase in unemployment, this means that a higher rate of increase in the real minimum wage causes an increase in the level of unemployment to a greater extent, or conversely a smaller rate of increase in the real minimum wage causes a smaller increase in unemployment. Thus, the increase in the real minimum wage causes cost-push inflation.

There is no trade-off between inflation and unemployment, this study do not support the Phillips curve. Inflation and unemployment have a positive and significant relationship. This means that higher inflation will be followed by higher unemployment.

The results of this study reject the results of research by Brouilletteet al (2017) on the effect of minimum wages on inflation. The results of this study support the results of research by Brunt \& Barilla (2018) on the effects of minimum wages on unemployment. The results of this study support the research results of Hasan \& Sun'an (2019), Anshori \& Suparta (2018), Idenyi et al (2017) on the effects of inflation on unemployment.

The minimum wage has a direct negative effect on inflation, inflation has a positive effect on unemployment, thus causing the minimum wage to have a negative effect indirectly on unemployment.

Only $5.5 \%$ of the variation in inflation is influenced by variations in minimum wages, and only $2.3 \%$ of variations in unemployment are affected by variations in minimum wages and variations in inflation. Thus many other variables affect inflation and that affect unemployment.

\section{References}

Adarkwa, S. (2017). The Impact of Economic Growth on Unemployment in Ghana: Which Economic Sector Matters Most? The International Journal Of Business \& Management, April 2017, 2321-8916. www.theijbm.com. 
Al-zeaud, H. (2014). The Trade-Off between Unemployment and Inflation Evidence from Causality Test for Jordan. International Journal of Humanities and Social Science, 4(4), 103-111.

Anshori, Z., \& Suparta, I. M. (2018). Pengaruh Pertumbuhan Ekonomi, Jumlah Angkatan Kerja, dan Inflasi Terhadap Tingkat Pengangguran di Provinsi Jawa Timur (2007-2016). Jurnal Ekonomi \& Bisnis, 3(2), 677686.

Arslan, M., \& Zaman, R. (2014). Unemployment and its Determinants: A Study of Pakistan Economy (1999-2010). SSRN Electronic Journal, 5(13), 20-25. https://doi.org/10.2139/ssrn.2515075.

Brouillette, D., Cheung, C., Gao, D., \& Gervais, O. (2017). The Impacts of Minimum Wage Increases on the Canadian Economy, Staff Analytical Notel Note analytique du personnel 2017-26. www.bank-banquecanada.ca.

Brunt, C. S., \& Barilla, A. G. (2018). An evaluation of the relationship between minimum wage and unemployment: does the local cost-of-living matter? Applied Economics Letters, 25(7), 493-498.

Doğan, T. T. (2012). Macroeconomic variables and unemployment: The case of Turkey. International Journal of Economics and Financial Issues, 2(1), 71-78.

Elliot, B. (2015). The Relationship between Inflation and Unemployment in Ghana-Analysis of the Philips Curve. African Journal of Economic Review, 3(2), 117-124.

Froyen, R. T. (2013). Macroeconomics: Theories and Policies. Tenth Edition. England: Pearson Education Limited.

Gyang, E.J., Anzaku, E., Iyakwari, A.D.B., \& Eze. (2018). An Analysis of the Relationship Between Unemployment, Inflation and Economic Growth in Nigeria: 1986-2015. Bingham Journal of Economics and Allied Studies (BJEAS), 1(1), 1-11.

Hasan, N., \& Sun'an, M. (2019). The Effect of Inflation and Private Investment on Open Unemployment in North Maluku (Partial Adjudication Model (PAM) Approach). Journal of Economics and Sustainable Development, 10(12), 67-76.

Idenyi, O., Favour, E. O., Johnson, N., \& Thomas. (2017). Understanding the Relationship between Unemployment and Inflation in Nigeria. Advances in Research, 9(2), 1-12. https://doi.org/10.9734/air/2017/32218.

ILO. (2015, December 3). Retrieved from Organization International Labor: https://www.ilo.org/global/topics/wages/minimum-wages/definition/WCMS_439072/lang--en/index.htm

Kasseh, P. A. (2018). The Relation between Inflation and Unemployment in the Gambia: Analysis of the Philips Curve. Journal of Global Economics, 06(02), 6-12. https://doi.org/10.4172/2375-4389.1000294.

Kim, C. U., \& Lim, G. (2018). Minimum wage and unemployment: An empirical study on OECD countries. Journal of Reviews on Global Economics, 7, 1-9. https://doi.org/10.6000/1929-7092.2018.07.01.

Levcic, R., \& Rebmann, A. (1986). Macroeconomics An Introducvtion to Keynesian-Neoclassical Controversies. London: Macmillan Education Ltd.

Ma, H. (2018). Will Wage Growth Drive Up Inflation? JULEX CAPITAL on MARCH 21, 2018, 1-3. Retrieved from https://www.etftrends.com/etf-strategist-channel/will-wage-growth-drive-up-inflation/

Macharia, M. K., \& Otieno, A. (2015). Effect of Inflation on Unemployment In Kenya. International Journal of Science and Research (IJSR), 6(6), 1980-1984. https://doi.org/10.21275/ART20174660.

Mankiw, N. G. (2000). Macroeconomics. New York: Worth Publishers.

Nguyen, C. (2011). Do Minimum Wage Increases Cause Inflation? Evidence from Vietnam. Retrieved from https://mpra.ub.uni-muenchen.de/36750/ MPRA Paper No. 36750, posted 18 Feb 2012 14:05 UTC

Sabir, G. M., \& Naz, S. (2015). Economic Determinants of Unemployment: Empirical Result from Pakistan. Journal of Economics and Sustainable Development, 6(9), 150-155.

Shahid, M. (2014). Effect of Inflation and Unemployment on Economic Growth in Pakistan. Interdisciplinary Journal of Contemporary Research in Business, 5(15), 103-107. https://doi.org/10.21275/ART20174660.

Thayaparan, A. (2014). Impact of Inflation and Economic Growth on. Global. Journal of Management and Business Research: B Economics and Commerce Volume, 13(5), 44-54.

Wascher, W. (2015). Minimum Wages. International Encyclopedia of the Social \& Behavioral Sciences, 561-565. https://doi:10.1016/b978-0-08-097086-8.94038-8.

Welch, P. J., \& Welch, G. F. (2010). Economics: Theory \& Practice. Hoboken, United States of America: John Wiley \& Sons. $\quad$ https://books.google.co.id/books?id=O5i-d3thv4C\&pg $=$ PA $146 \& l p g=P A 146 \& d q=$ four + macroeconomic + sectors $+\% 22$ households $\% 22+\% 22$ businesses $\% 22$ $+\% 22$ government $\% 22+\% 22$ foreign $\% 22 \&$ source=bl\&ots=DYalEGh7AJ\&sig=ACfU3U3U4Z3Gya5HBb9i3 TLz1EohyVXDYA\&hl=en\&sa $=$. 